\title{
Innovative Research on Mechanism of Ideological Education in Colleges
}

\author{
Chunxiang Shu \\ Jiangxi Environmental Engineering Vocational College, Ganzhou, Jiangxi, 341200
}

Keywords: Ideological Education, College Education, Innovative Research

\begin{abstract}
The party and the state have always attached great importance to ideological and political education in colleges and universities. However, their achievements have not been notable enough and they are hard to cope with the challenges posed by globalization and the socialist market economy to personnel training in higher education institutions. The fundamental problem lies in the mechanism. The drawbacks of the traditional ideological and political education system formed under the conditions of a planned economy have gradually become exposed. The inability to adapt to the new situation in the socialist market economy and the new changes in higher education has triggered conflicts in the new environment. Therefore, to meet the trend of the times, ideological and political education in colleges and universities must carry out all-round reform and innovate ideological and political education mechanisms.
\end{abstract}

\section{Introduction}

The ideological and political education of university students places great emphasis on the ideological and political education of the party and the country, has a clear guiding principle, repeatedly emphasizes the need to strengthen and improve, and clearly stipulates important issues such as its status and role, principles and principles, contents and approaches, methods and means . Comrade Hu Jintao pointed out: "It is a fundamental issue that must be solved in the development of socialist education in our country to cultivate anybody and how to train people." However, in many universities, the actual purpose and effect can not achieve the desired goal ? An important reason is that there are problems in the mechanism and there is no real establishment of a scientific and sound working mechanism. Therefore, at the same time we must probe into the innovation of ideological and political education among college students, we must probe into the innovation of the working mechanism of ideological and political education for college students, which is the inevitable choice of historical development.

\section{Analysis of the status quo of ideological and political education in colleges and universities}

With the deepening of reform and opening up and the profound changes in the international and domestic situations, undergraduates face a great deal of impact from Western cultural trends and values. The development of the socialist market economy, the social and economic components, organizational forms, employment patterns, interest relations and distribution The diversification of modes and the increasing independence, selectivity, variety and diversity of people's ideological activities are conducive to establishing a sense of self-reliance, sense of innovation, sense of accomplishment and sense of pioneering among undergraduates, and at the same time they also bring negative effects that can not be ignored. At present, the values of undergraduates show more complicated situations. The mainstream is positive and progressive, but the minority also shows the tendency of extreme individualism and money worship. Their ideal pursuits are contrary to actual actions. The value orientation of some students has been impacted. With more and more personal preferences and personal interests, the tendency of the secular and utilitarian material in their concepts is becoming more and more obvious. Some college students have varying degrees of confusion, vague ideals and beliefs, distorted values, weak sense of integrity, lack of social responsibility, weakness in hard work, poor ideas of solidarity and coordination, and poor psychological quality. The ideas and values of college students develop toward diversification and 
complication, which mainly manifests in the fact that the value subject is self-centered, the value orientation is utilitarian, and the moral concept is complicated. Some students think "ideal ideal, favorable think; future, rich figure," and some students think that "the ideal is far, the belief is false, the money is real. Drop imaginary, fishing for real. " However, the responsibility, obligation and contribution to society are rarely considered. In the face of the diversified ideological concepts and values of the subjects being educated, ideological and political education for college students still adopts a "one-size-fits-all" approach. As a result, ideological and political work can not achieve the expected results.

With the transformation of the entire social and economic system, the demand for qualified personnel tends to be diversified. However, the existing education system still follows the traditional mode of education under the planned economy and adopts a single approach to student education. In the course of setting the curriculum uniform row, not according to the actual situation of students, targeted education, students in learning, career choice of different options, it is bound to make their ideological conditions there are some differences, and this single teaching The training mode can not meet the requirements of increasingly diversified types of students. Students' confusion can not be solved and can not be properly guided. The simplification of ideological and political work education in colleges and universities has made it to a certain degree of loss of pertinence and effectiveness. In view of the diversification of types of talents, ideological and political work in universities should change the traditional single mode of education. Students have different backgrounds, different environments and different problems. Their characteristics and requirements of their ideological activities will also be different. Colleges and universities should proceed from actual conditions, analyze specific situations, solve specific problems in a concrete way, System should be due to circumstances and measures, due to the right conditions, and constantly improve the ideological and political work in colleges and universities "input-output ratio."

The reform and opening up and the socialist market economy have brought about the rapid economic development in China and the enormous social progress. At the same time, the degree of development of the entire social life has been greatly enhanced. People's awareness of competition, awareness of efficiency, awareness of democracy and legal system and pioneering and innovative awareness have been enhanced, The whole social life shows a completely new attitude. From the perspective of the specific conditions of colleges and universities, students are more active in thinking, well-informed and well-received, and their thinking conditions are more complex. Their pluralistic ideology and value orientation are more obvious. Among them, the correct, advanced, newborn and positive thinking concepts and values are the mainstream, but at the same time we must also be soberly aware that the common development of various economic sectors and the emergence of various interest groups will enable some students Confusion or chaos in thought, psychological imbalance, weak ideals and beliefs, poor professional ethics and social morality; influenced by various concepts of life and spiritual needs, the emergence of liberalism, utilitarianism, money worship, hedonism, individualism The decadent ideology has brought some negative effects to some students. The world outlook, outlook on life and values have deviated. Due to the diversification of employment forms and employment forms, some problems such as employment difficulties, employment difficulties and laid-off workers have caused great deeds among some students Stress and dissatisfaction.

\section{The Basic Train of Thought for Innovating the Mechanism of Ideological and Political Education in Colleges and Universities}

In general, the management mechanism of ideological and political education in colleges and universities is the adjustment, control and optimization of the ideological and political education activities in colleges and universities by the managers of ideological and political education in order to achieve the goal and effect of ideological and political education in colleges and universities. Specifically includes the following several closely related aspects and links: the ideological and political education in higher education leadership mechanism, incentive mechanism and evaluation 
mechanism. Process mechanism is the core and key point of ideological and political education in colleges and universities. Broadly speaking, the mechanism of ideological and political education in colleges and universities is a process mechanism. What we are discussing here is the course of the ideological and political education constituted by the organizational structure, the actors and their behavior of undertaking specific functions of ideological and political education during the concrete operation of the ideological and political education system in colleges and universities. In short, it is the concrete implementation of ideological and political education in colleges and universities. The process mechanism is exceptionally complex, involving all aspects of ideological and political education in colleges and universities.

Under the condition of socialist market economy, the ideological and political education of college students should change from the traditional way of thinking to the modern way of thinking, and establish an open, systematic, dynamic and scientific way of thinking. First, establish an open mindset. Faced with the unprecedented opening up of the social field brought about by the socialist market economy, we must use the concept of openness to understand and analyze problems, expand the area of thinking, broaden the space for thinking, speed up the pace of thinking, and shorten the thinking process. The content and form of ideological and political education , Methods, based on a full range of multi-angle thinking, so that their thinking is not only in line with vivid reality and the characteristics of students, but also keep up with the trend of the times so that ideological and political education with the minimum investment to maximize social benefits. Second, establish a systematic way of thinking. It is necessary to correctly handle the relationship between educational objects and various elements of the ideological and political education system from a systematic and overall perspective and correctly handle the relationship between ideological and political education and other university jobs. According to the systematic characteristics of the ideological and political education itself, the educational object should be investigated in the form of the system so as to be guided by the systematic thinking and use the systematic method to observe, analyze and solve the difficulties and problems encountered by the ideological and political education of the university students . Once again, establish a dynamic way of thinking. To do a good job in ideological and political education of college students, we must change the traditional way of static thinking. Because ideological and political education is facing the situation, tasks, objects and environment are often in change, which determines the ideological and political education in colleges and universities at any time to face some new love wishes, new problems, ideological and political education workers must change constantly The actual situation, the ideological and political education of college students using dynamic planning, dynamic control, rational organization, coordination, scientific analysis, careful grasp of the relationship between the various methods to complement each other, and constantly adjust the proportion of different methods, at any time to change the invalid or out of date Approach, using a targeted and effective approach.

All educational activities need to be based on a certain material basis, require some manpower support, require some institutional support to correct some possible deviations and errors, absorb new ideas and practices in education, and provide long-term stability The guiding mechanism to promote the continuation of educational activities is the safeguard mechanism. Ideological and political education in colleges and universities as a kind of special educational activities also need this guarantee mechanism. It is an indispensable part of the ideological and political education system in colleges and universities, and also a weak link in the current ideological and political education system in colleges and universities. The effective operation of the ideological and political education system in colleges and universities must be ensured with certain input. In order to improve the effectiveness of ideological and political education in colleges and universities, we must make greater efforts in funding and material aspects. In the information society, the work of ideological and political education for students can not be confined to the classroom. The dormitory orally states that it needs certain places and advanced equipment, optimizes the means of education, and implements a wide range of education. Colleges and universities should change the practice of relying solely on "one mouth" to increase funding and improve teaching conditions. The input of funds should not only include recurrent theoretical funds for education, funds for publicity and 
education activities, but also funds for practical research and social investigation. It should not only include the funds for library materials but also include funds for audiovisual equipment and multimedia. Not only To provide education objects in all aspects of funding, but also include education and training, study funding; not only have indoor equipment, but also include the construction of outdoor activities, funding. Therefore, it is necessary to maximize the efficiency of using funds from the reality of contemporary society so as to enhance the effect of ideological and political education in colleges and universities.

Colleges and universities should incorporate the construction of modern moral education facilities, equipment, and activity sites and bases adapted to the moral, intellectual and physical development of students into the overall construction plan and guarantee them from the capital construction and equipment costs. Ideological and political education guarantee system facilities, equipment and activities venues, construction should be oriented to the modernization, should be good at using modern technology to arming moral education. At the same time, it is necessary to pay attention to studying and strengthening the ways and means of using multimedia technology to improve the guarantee system of ideological and political education, studying how to fully develop Internet resources, using Internet technology to establish a website for guaranteeing ideological and political education, implementing online moral education, network security and continuously improving colleges and universities The Modernization of the Construction of the Guarantee System of Ideological and Political Education.

\section{Conclusion}

The innovation of management mechanism mainly explores the innovation of leadership mechanism, incentive mechanism and evaluation mechanism of ideological and political education in colleges and universities. The innovation of process mechanism mainly discusses the integration of process mechanism and market mechanism in college ideological and political education, and cultivates the self-education ability of college students And through social practice to enhance social education tension; the protection mechanism of innovation mainly from three aspects of material, institutional and environmental aspects of ideological and political education in colleges and universities innovation.

\section{References}

[1] Li Yue. On the construction of university ideological and political education environment and optimization [J]. Shanxi Journal of Social Sciences. 2007 (05)

[2] Geng Yanjun. Discussion on the basic principles of ideological and political education in colleges and universities [J]. Social Sciences Forum. 2007 (04)

[3] Wang Meixian, Dai Zhaotun. Self-education is an important way to improve the effectiveness of ideological and political education of college students [J]. Modern University Education. 2007 (02)

[4] Marchike. On the ideological and political education guarantee mechanism [J]. School Party Building and Ideological Education 2007 (02)

[5] Shen Xia. Optimization investment: to enhance the ideological and political education of the actual demand [J]. Higher Education Forum 2006 (06)

[6] Weng Shihuan. Analysis of college students self-education [J]. Journal of Hunan University of Science and Technology. 2006 (06) 